\title{
Hydrogeomorphological mapping using geospatial techniques for assessing the groundwater potential of Rambiara river basin, western Himalayas
}

\author{
Rayees Ahmad Shah ${ }^{1} \cdot$ Suhail Ahmad Lone ${ }^{2}$
}

Received: 6 September 2018 / Accepted: 20 March 2019 / Published online: 30 March 2019

(c) The Author(s) 2019

\begin{abstract}
Integration of geospatial techniques (remote sensing and geographical information system) for the identification of groundwater potential has become an important tool in evaluating, monitoring and conserving groundwater resources. Effective utilization of groundwater resources has become important due to changing climatic scenario. Hence, estimating the zones of potential groundwater recharge is extremely important for the protection and management of water quality of groundwater systems. In this study, Rambiara river basin, southern-eastern part of Kashmir valley, was examined to assess its groundwater resource potential. Geospatial techniques were used to assimilate five causative factors: lithology/geology, land use and land cover, lineaments, drainage, and slope. The factor weight contributing to the groundwater recharge was acquired using satellite image data, lithological/geological maps, and a land use/land cover database followed by field validations. Based on the results obtained, it was observed that the premier recharge potential zones are located down the slope of the river basin due to the dominance of alluvium and agricultural land. Hard rock lithology located towards upstream areas of the basin allows less water to infiltrate.
\end{abstract}

Keywords Geospatial · Landsat · Groundwater · Digital elevation model

\section{Introduction}

Groundwater is an important natural resource of fresh water for potable water supply in both urban and rural environment (Fashae et al. 2014; Lone et al. 2016). It plays a substantial role in human life, as well as that of some aquatic and terrestrial ecosystems. Presently groundwater contributes about $34 \%$ of total annual water supply in most parts of the India (Magesh et al. 2011). The snow and glacier melt waters sustain the surface water flow in Kashmir Himalayas (Lone et al. 2017). Climate change, change in form of precipitation and a decreasing trend in the snowfall and river flow (Lone et al. 2016), is leading to water shortage, which has laid more emphasis on groundwater resources. Continuous

Rayees Ahmad Shah

shahrayees04@gmail.com

1 Department of Geology, Anna University, Chennai 600 025, India

2 Department of Earth Sciences, University of Kashmir, Srinagar, Jammu and Kashmir 190 006, India availability and easy accessibility with excellent natural quality of groundwater make it more important source of water supply for domestic usage around the world (Todd and Mays 2005). The groundwater makes up $97 \%$ of the liquid freshwater available on the earth's surface, used for drinking and other domestic usage (Foster 1998). However, mismanagement and overexploitation of the groundwater resource have led to water shortages and pollution (Tsakiris 2004; Nag and Ghosh 2013). Consequently, the overexploitation of groundwater particularly in developing countries is becoming a key concern (Todd and Mays 2005; Pinto et al. 2017). It is very important to make economically efficient usage of groundwater, since this resource is limited. Geospatial technologies (remote sensing and GIS) are very significant to constantly evaluate and monitor the groundwater resource (Jasmin and Mallikarjuna 2015; Mallick et al. 2015). Reliably base line information about factors (geology, land use, land cover, drainage, lineaments) controlling and effecting the occurrence and movement of groundwater can be quantified using satellite data and geospatial techniques (Bobba et al. 1992; Meijerink et al. 2000; Magesh et al. 2011). However, because of the non-availability of the 
data and integrating tools, all such factors had not often been studied together. Remote sensing and geographic information are important for study of hydrogeological data and for the virtual modelling of multifaceted features (Watkins et al. 1997; Gogu et al. 2001; Gossel et al. 2004).

Since only limited work in this field has been carried out in the Kashmir valley, so far only inadequate information about precipitation variation, river water flux, hydro-geological properties, groundwater consumption, and groundwater recharge is available. Water resources in the Kashmir valley are shrinking due to changing climate and economic development. It is very important to characterize and plan for groundwater resources development, particularly for the mountainous terrain of the Kashmir valley. The decreasing groundwater level in the mountain area is an indication of the decrease in groundwater resources (Yeh et al. 2007). So, this work is emphasized to identify and map the groundwater potential zones of Rambiara river basin for the development and management of groundwater resources for sustainable usage.

\section{Study area}

The Rambiara river basin is one of the left bank mountainous catchment of river Jhelum in the western Himalayas, which lies between latitudes $33^{\circ} 33^{\prime}$ and $33^{\circ} 54^{\prime} \mathrm{N}$ and longitudes $74^{\circ} 30^{\prime}$ and $75^{\circ} 00^{\prime} \mathrm{E}$ towards south Kashmir valley and covers an area of $660 \mathrm{~km}^{2}$, and is presented in Fig. 1.

The area experiences a temperate climate and receives average precipitation of about $693 \mathrm{~mm}$ year $^{-1}$. Snow is the dominant form of precipitation during winter and early spring seasons, and precipitation falls in form of rain during rest of the year. Maximum rainfall of the year is mainly received in the month of March $(183 \mathrm{~mm})$ and least in November $(36 \mathrm{~mm})$. Daily average maximum temperature is experienced in the month of July at about $33^{\circ} \mathrm{C}$, while the minimum temperature decreases down to $-5^{\circ} \mathrm{C}$ in January, with a mean annual temperature of around $11^{\circ} \mathrm{C}$.

\section{Materials and methods}

The base map of Rambiara river basin was prepared using survey of India topographic maps on an average scale of 1: 25,000. The drainage map for the Rambiara basin was prepared in ArcGIS 10.4.1 using arc hydro tool. The slope map was prepared from Aster DEM data of $30 \mathrm{~m}$ resolution in ArcGIS Spatial Analyst module. The drainage density, lineament density and lithological maps were prepared using line density analysis tool and on screen digitization methods in ArcGIS. Satellite data (Landsat ETM+) on a scale of 1:50,000 (geo-coded, with UTM projection, spheroid and datum WGS 84) were used for demarcation of thematic layers such as land use, lithology,

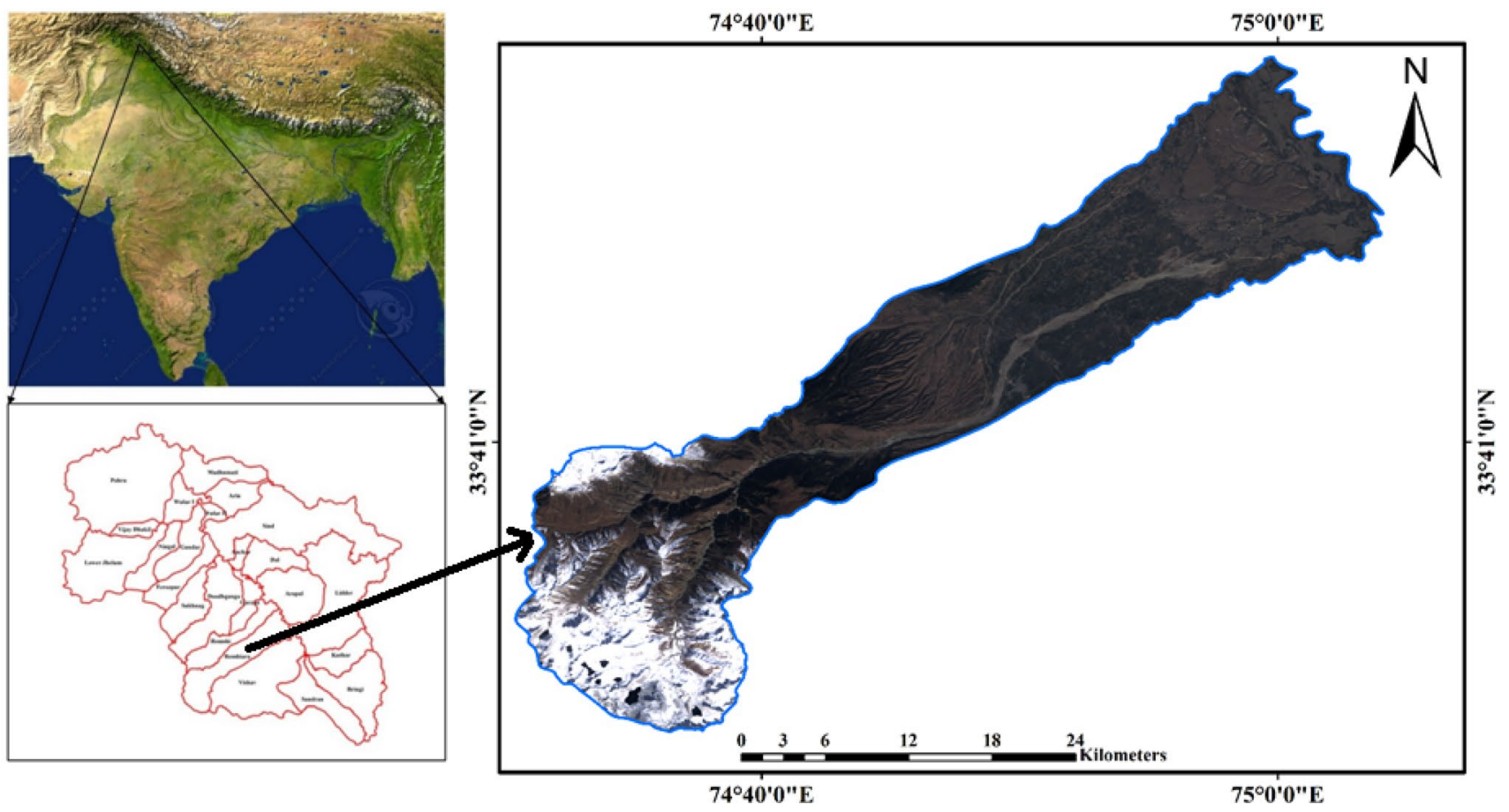

Fig. 1 Study area map showing location of Rambiara river basin 
lineament. These thematic layers were transformed into a raster format (30 m resolution) and then brought into GIS environment. The overlapping of the entire thematic layer in ArcGIS 10.4.1 using geospatial analysis tool was done to acquire the different groundwater potential zones. The factors affecting groundwater recharge potential are listed in Table 1.

Table 1 Factors influencing groundwater recharge

\begin{tabular}{ll}
\hline Factor & Basis of categorization \\
\hline Lithology & $\begin{array}{c}\text { Rock type, weathering character, joints, } \\
\text { fractures } \\
\text { Type, areal extent, associated vegetation }\end{array}$ \\
Land cover/land use & $\begin{array}{l}\text { Lineament-density value } \\
\text { Lineaments }\end{array}$ \\
Drainage & Drainage density value \\
Slope & Slope gradient \\
\hline
\end{tabular}

\section{Results and discussions}

\section{Evaluating physical and environmental factors controlling groundwater occurrence}

\section{Geomorphology}

The main geomorphic units identified in the area are alluvial plain, gentle slopes/residual hills mountainous ridges, moderately dissected hills, glaciated terrains/highly dissected hills, river channels, proglacial lakes and denudational hills as represented by geomorphology Fig. 2 and field evidence Fig. 3. Alluviums, moderately dissected hills followed by glaciated terrains are the dominant types of geomorphological class in the watershed. Recent alluvium and gentle plain are promising groundwater potential areas due to high infiltration rates, while the glaciated terrains and mountain ridges have shown less impact in

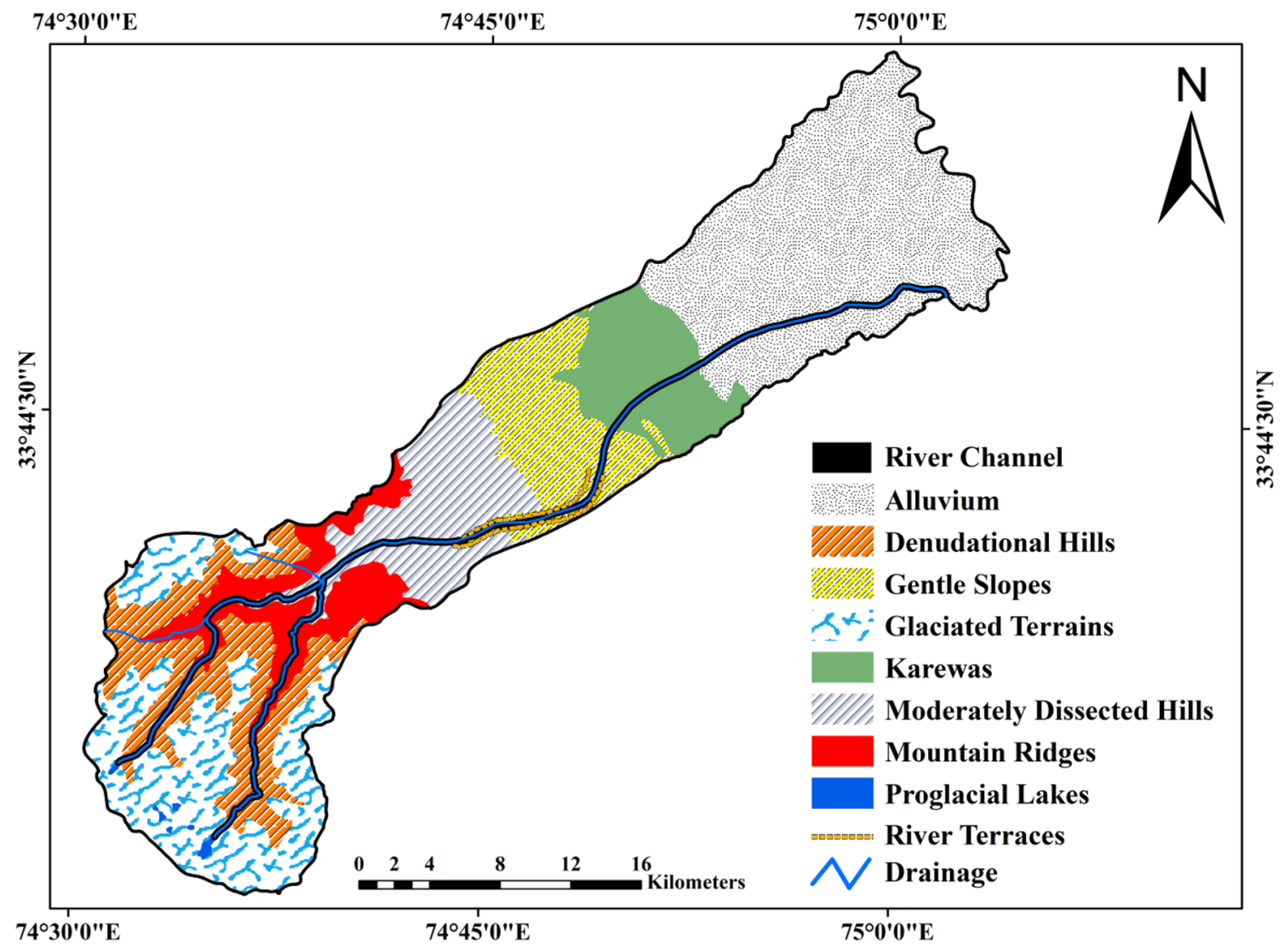

Fig. 2 Geomorphology of the study area 

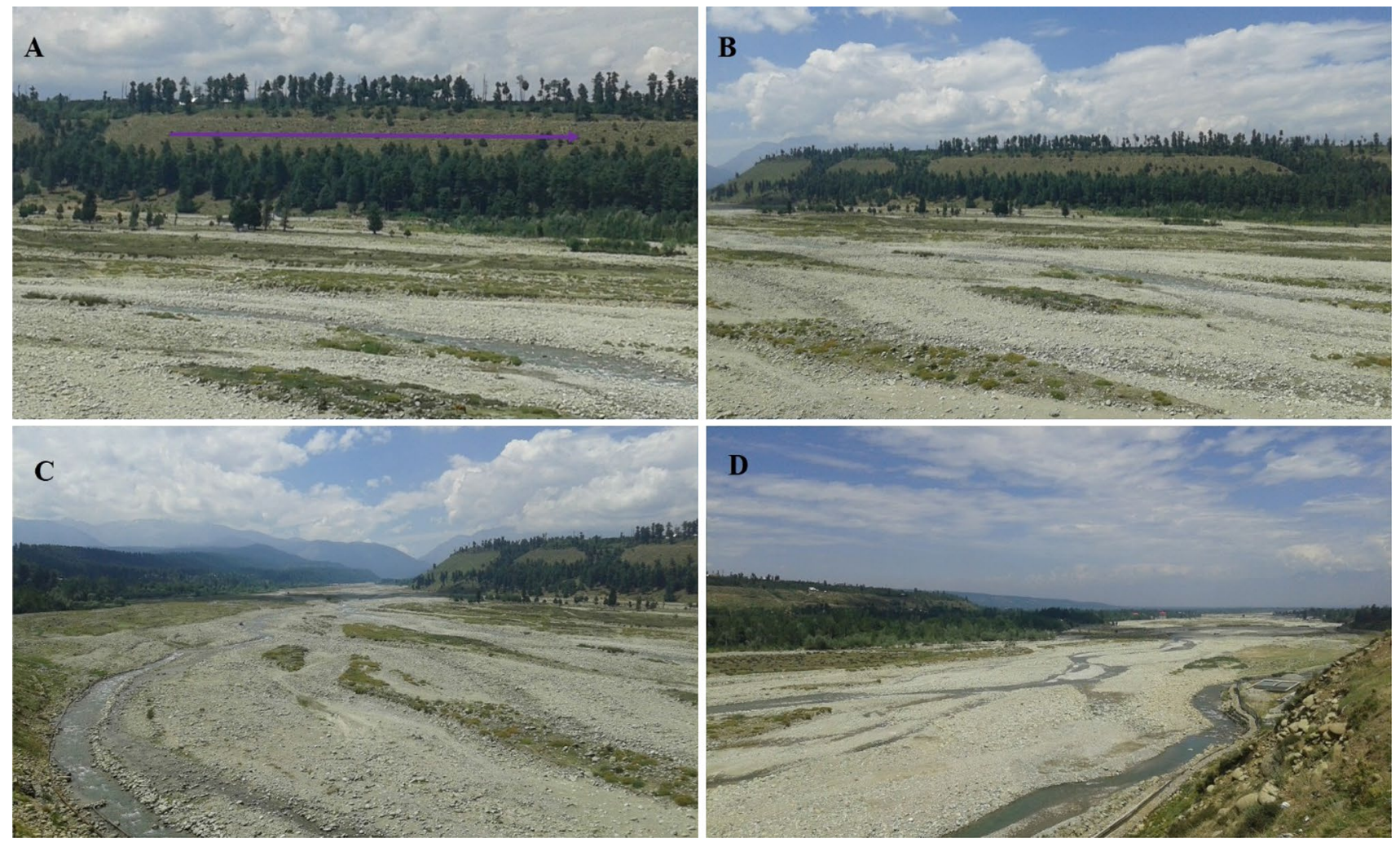

Fig. 3 Field evidences of different geomorphic units in Rambiara river basin. a River Terrace, $\mathbf{b}$ alluvial plain and $\mathbf{c}, \mathbf{d}$ braded river channel, river meandering

controlling groundwater due to less porosity and higher slopes (Soumen 2014; Lone et al. 2016).

\section{Lithology}

Lithology is another important factor controlling the quantity and quality of groundwater occurrence in the Rambiara river basin. The lithology of the study area (Fig. 4) is dominated by recent alluvium towards the lower altitude, Panjal traps (Carboniferous), Limestone (Triassic Jurassic) and Agglomeratic slates (Carboniferous) towards the high altitude upper regions.

The lithology affects hydrogeological properties of aquifers. The dominating class, recent alluvium in the lithology map (Fig. 4), is composed of silt-sized sediments with a mixture of fine sand and clay deposited overlaying Karewa deposits. The Karewa deposits are fluvio-lacustrine, glacio-fluvio-lacustrine and aeolian origin composed of clay, silt, sand and boulders (Agarwal et al. 2018) of about $4 \mathrm{Ma}$ old and about $1300 \mathrm{~m}$ thickness. This class is the most appropriate and promising groundwater potential area in the lithology because on high porosity created by the loose and unconsolidated sediments. Another promising area of groundwater recharge is the area with limestone lithology rocks, because of its high secondary porosity.

\section{Drainage density}

The drainage-length density $\left(D_{\mathrm{d}}, L^{-1}\right)$, as defined by Greenbaum (1985), indicates the total drainage length in a unit area and is determined by:

$D_{d}=\frac{\sum_{i=0}^{i=n} S i}{A}$

where $\sum_{i=0}^{i=n} S i$ denotes the total length of lineaments $(L)$ and $A$ denotes the unit area $\left(L^{2}\right)$. A high lineament-length density infers high secondary porosity, thus indicating a zone with high groundwater potential (Yeh et al. 2008). The drainage density of the study area was classified and is presented in Fig. 5. The drainage density map distinctly shows three 


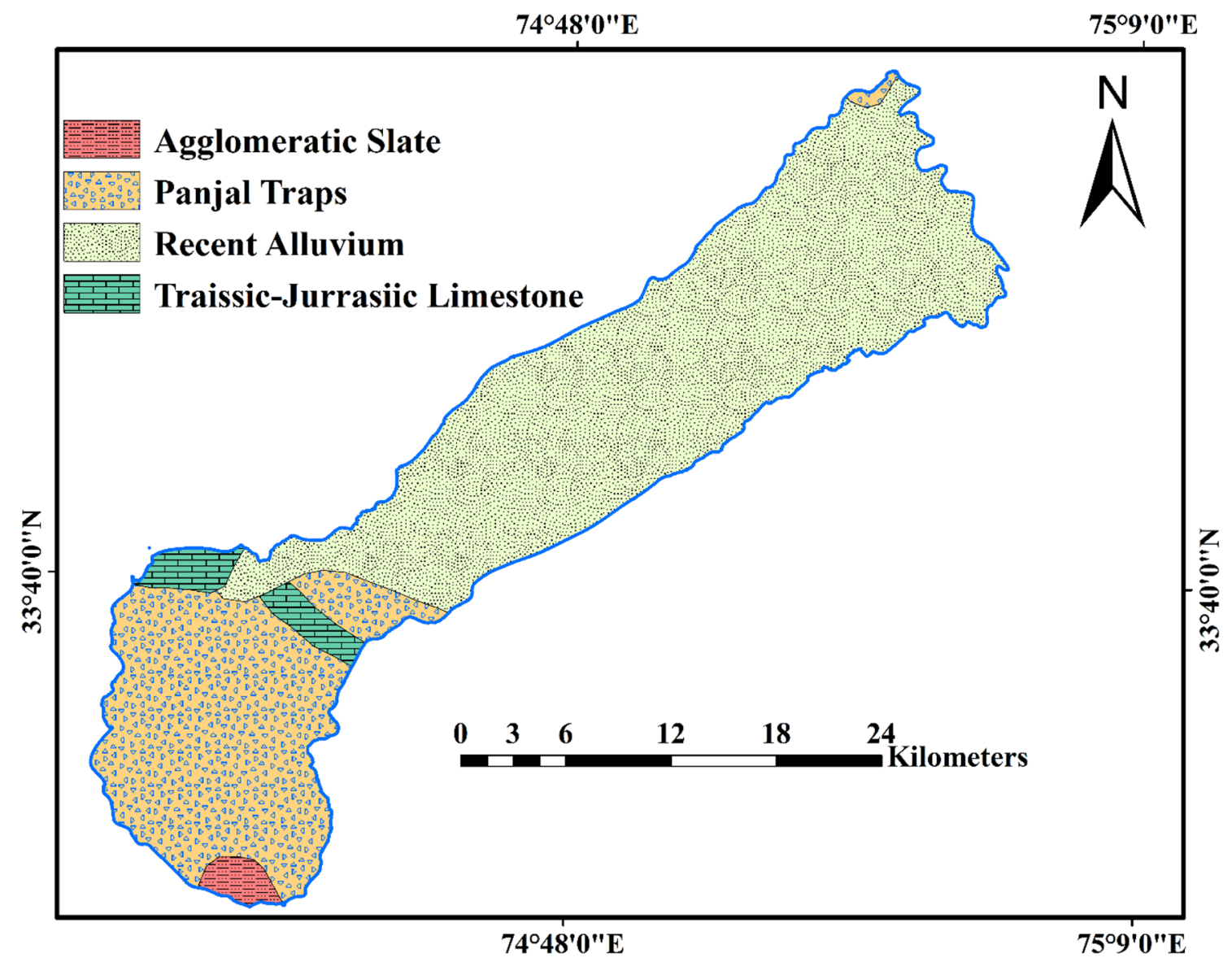

Fig. 4 Lithological map of study area. Modified after Thakur and Rawat (1992)

drainage density categories that have been identified and mapped as shown in Fig. 5.

Very high drainage density in the study area is located in the northeastern parts or lower parts of the study area, which is composed of recent alluvium sediments. On the other hand, areas with very low drainage density are found in the high altitude region in south-western parts of the study area. The areas towards the centre of the study areas contain moderate to low drainage densities. The high drainage texture indicates highly porous and permeable rock formations, whereas the fine drainage texture is more common in less previous and fractured rock formations. Structurally controlled drainage is normally observed in the south-western part of the study area. Drainage texture and patterns are also controlled by different litho-units, structure and morphology. In the study area, the drainage pattern is dendritic to sub-dendritic. Groundwater potential is very poor in those areas with very course drainage density, as it loses the bulk part of precipitation water in form of runoff. However, low drainage density areas allow water to infiltrate to recharge the groundwater and, therefore, have more potential for groundwater occurrence. On the other hand, high drainage density values are promising for runoff and hence designate low groundwater potential zone (Terzer et al. 2013).

\section{Land use/land cover}

The land use/land cover (LULC) of area depends on geomorphology, agro-ecology, climate and human-induced activities. It is one of the factors affecting groundwater occurrence and availability. LULC information is a main factor in assessing the groundwater storage and recharge of the area, the type and nature of LULC controlling the groundwater in order of increment is as: forests, cultivated land, barren land and built-up. Therefore, forest and cultivated areas (agriculture and horticulture) are more appropriate for groundwater occurrence because of better infiltration rates. The degree of cultivation is also intensified due to the presence of good groundwater potential. 


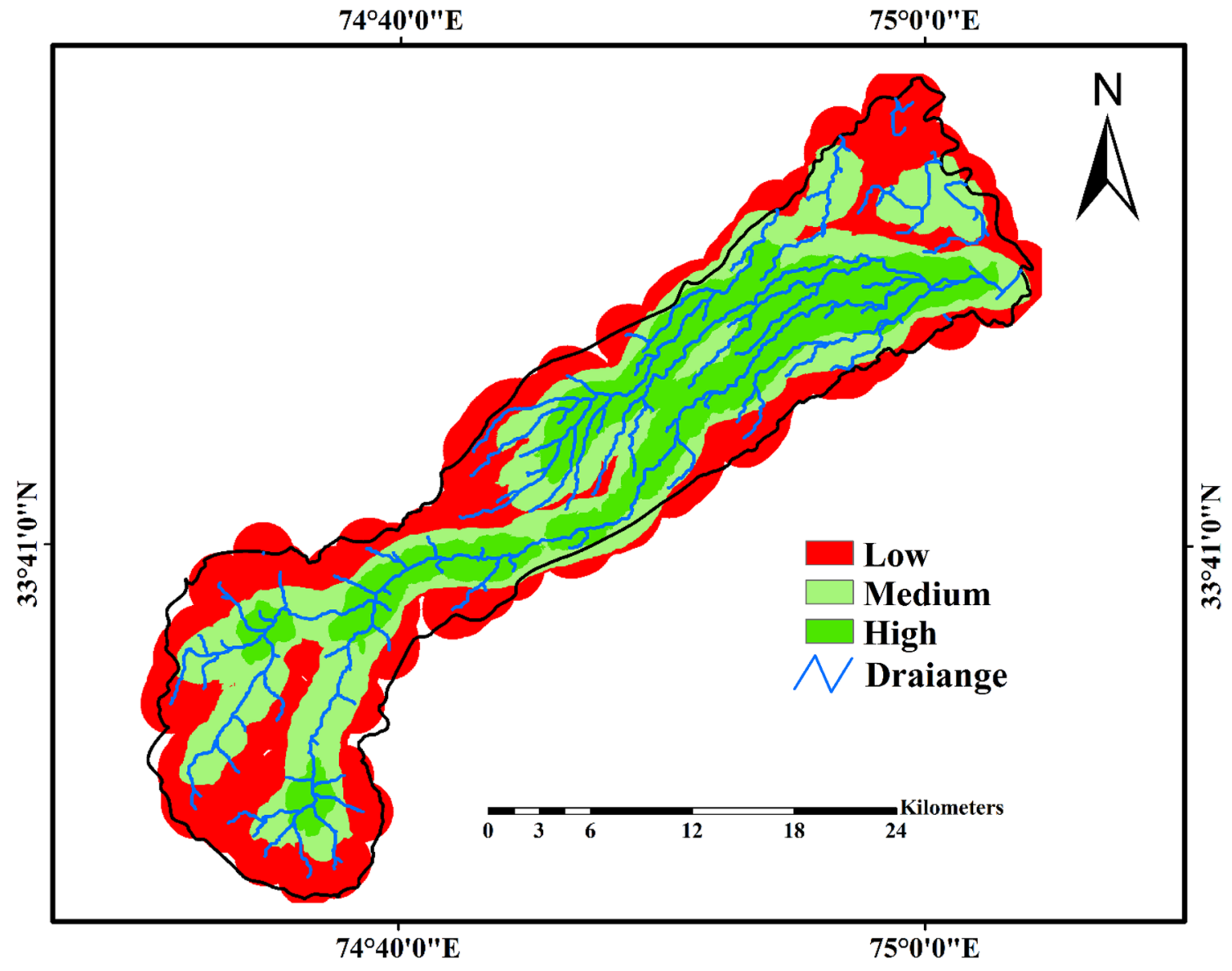

Fig. 5 Drainage density/drainage map of the study area

For LULC classification of the study area, Landsat satellite image of 2016 with $30 \mathrm{~m}$ spatial resolution was used as a source of data to derive the LULC map. Supervised image classification is conducted to classify and to identify the type of LULC, categorized the study area into six classes, and is presented in Fig. 6. The six classes include built-up, forests, cultivated area (agriculture and horticulture), barren land, water bodies and snow and glacier cover.

The high altitude part of the study area towards the southwest is dominated by snow cover and barren land class, due to its high altitude geomorphology and hard rock lithology. This area falls in low potential groundwater recharge zone. A large area towards the central part of the study area is dominated by forest, cultivated land, and thus forms an area of the maximum potential groundwater recharge zone. The low altitude plains towards the northeast are dominated by the urbanized built-up. As the urbanization poses hindrance in groundwater recharge, this makes it the zone of low potential groundwater recharge. Yellow region in Fig. 7 shows patches of built-up distributed throughout, which is a major concern in the future of groundwater recharge. Increase in the human population in the area results in converting more and more agriculture land into the urbanized area. Thus increasing population and the growing demand for the groundwater is shrinking the areas of potential groundwater recharge and is inversely affecting the groundwater.

\section{Lineament density}

Lineament-length density $\left(L_{\mathrm{d}}, L^{-1}\right)$ (Greenbaum 1985), which represents the total length of lineaments in a unit area, is calculated as follows:

$L_{\mathrm{d}}=\frac{\sum_{i=0}^{i=n} L i}{A}$

$\sum_{i=0}^{i=n} L i$ denotes the total length of drainage $(L)$ and $A$ denotes the unit area $\left(L^{2}\right)$. A high lineament-length density infers high secondary porosity, thus indicating a zone with high groundwater potential (Yeh et al. 2008). 


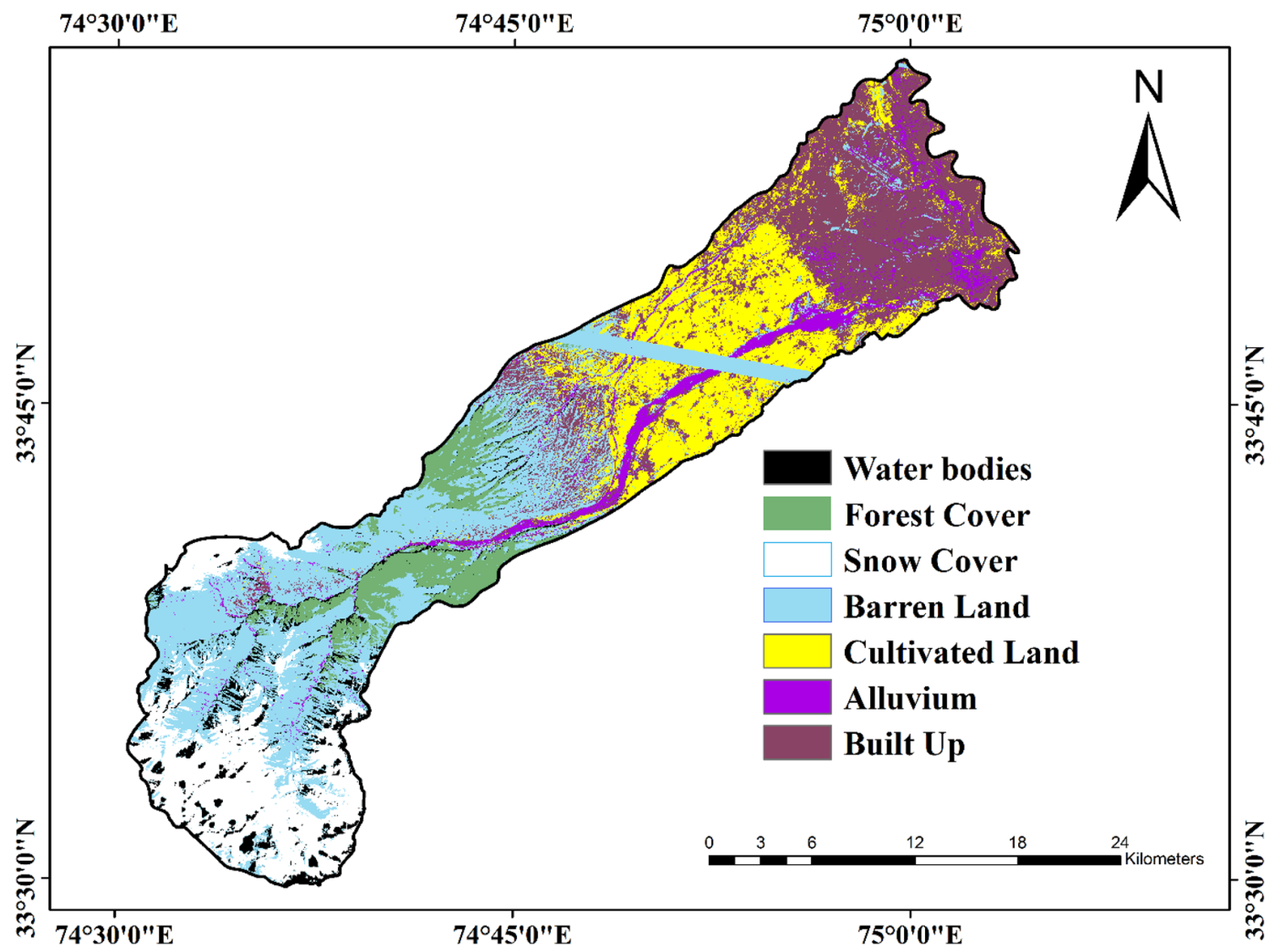

Fig. 6 Land use/land cover of study area

Maximum lineament density areas are more hospitable to infiltration and recharge and, therefore, are good potential areas for groundwater occurrence (Bhuvaneswaran et al. 2015, Lone et al. 2016). The areas with gentle slope have good potential for groundwater availability due to less runoff. Figure 7 shows the processed lineament map of the study area. A high lineament-length density designates high secondary porosity, thus signifying a zone with high groundwater potential (Al-Abadi and Al-Shamma' a 2014). The lineament density map of Rambiara river basin reveals that the high lineament density is observed towards a high altitude of the study area due to the presence of hard rock lithology.

\section{Slope aspect}

The slope aspect is one of the most significant factors controlling and modifying groundwater occurrence. Low slope areas have the capability of holding the precipitation and enabling recharge to groundwater as compared to steep slope areas, where water moves as run off immediately (Sisay 2010). Figure 8 represents the slope aspect map of the Rambiara river basin; as shown in the figure, the lower part of the study area that is highly covered by built-up and cultivating land is almost flat, having a slope degree value of $0-10$ of the catchment, and thus forms the idle condition for the potential groundwater recharge zone. The central part, which is covered by forests and cultivation land with slope values of 10-20 and 20-30, is classified as gentle and moderate slope area, respectively. The area around the south-west and western parts of the catchment is steep having a slope value of 30-60 covered by barren and glaciated terrains. The results further represent that slopes with flat (1-10) and gentle areas (10-20) are more appropriate for groundwater existence as compared to steep slopes, because gentle and flat slope areas permit less runoff and thus have very good groundwater recharge potential (Hussein et al. 2016).

\section{Groundwater prospecting and validation}

The groundwater potential areas were recognized by integrating different potential factors, including geological structures, lithology, geomorphology, slope, land use/land 


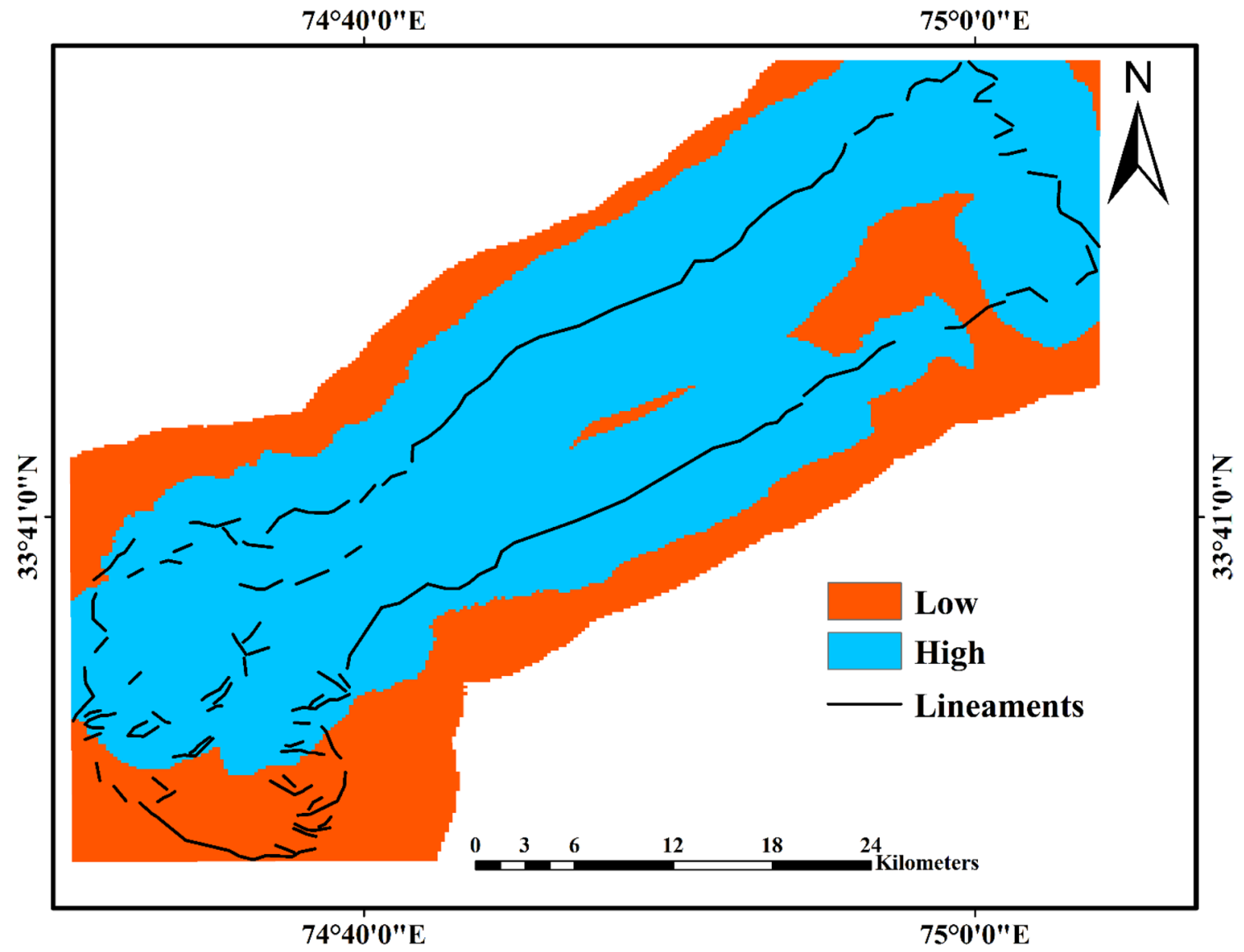

Fig. 7 Lineament density/lineament map of study area

cover drainage in GIS environment (Waikar and Nilawar 2014; Ayele et al. 2014). For the present study, the groundwater prospect map of the study area was prepared by integrating different thematic layers in GIS environment and is presented in Fig. 9.

Our results show that the groundwater recharge potential zone of Rambiara river basin can be divided into seven grades, namely very high, high, moderate, low, very low, poor and very poor, based on the examination of the five factors (lithology, land use/land cover, lineaments, drainage, and slope) of groundwater recharge potential. Analytical results demonstrate that the excellent groundwater recharge potential zone is concentrated in the downstream region due to the presence of alluvial plains, gentle slope and occurrence of cultivated land and forests that support a high infiltration capability. Additionally, the concentration of drainage also helps the stream flow to recharge the groundwater system. The high altitude upstream region towards southwest direction supports low infiltration due to the influence of less fractured igneous and metamorphic rocks with steep slopes. Since the groundwater recharge potential of the particular area is directly linked with percolation, the scores obtained may be more precise and impartial if the laboratory techniques were used to measure the rate of percolation and hydraulic conductivity of each recharge potential factor. Potential factors that affect groundwater recharge in a small area, such as alteration in terrain and river courses caused by an earthquake, or modification in land utilization in a small area can be quantified using the grid model to estimate groundwater recharge potential zones. The modelled results can be validated by applying isotopic tracer technique while considering the quantity of pumped groundwater against groundwater recharge. 


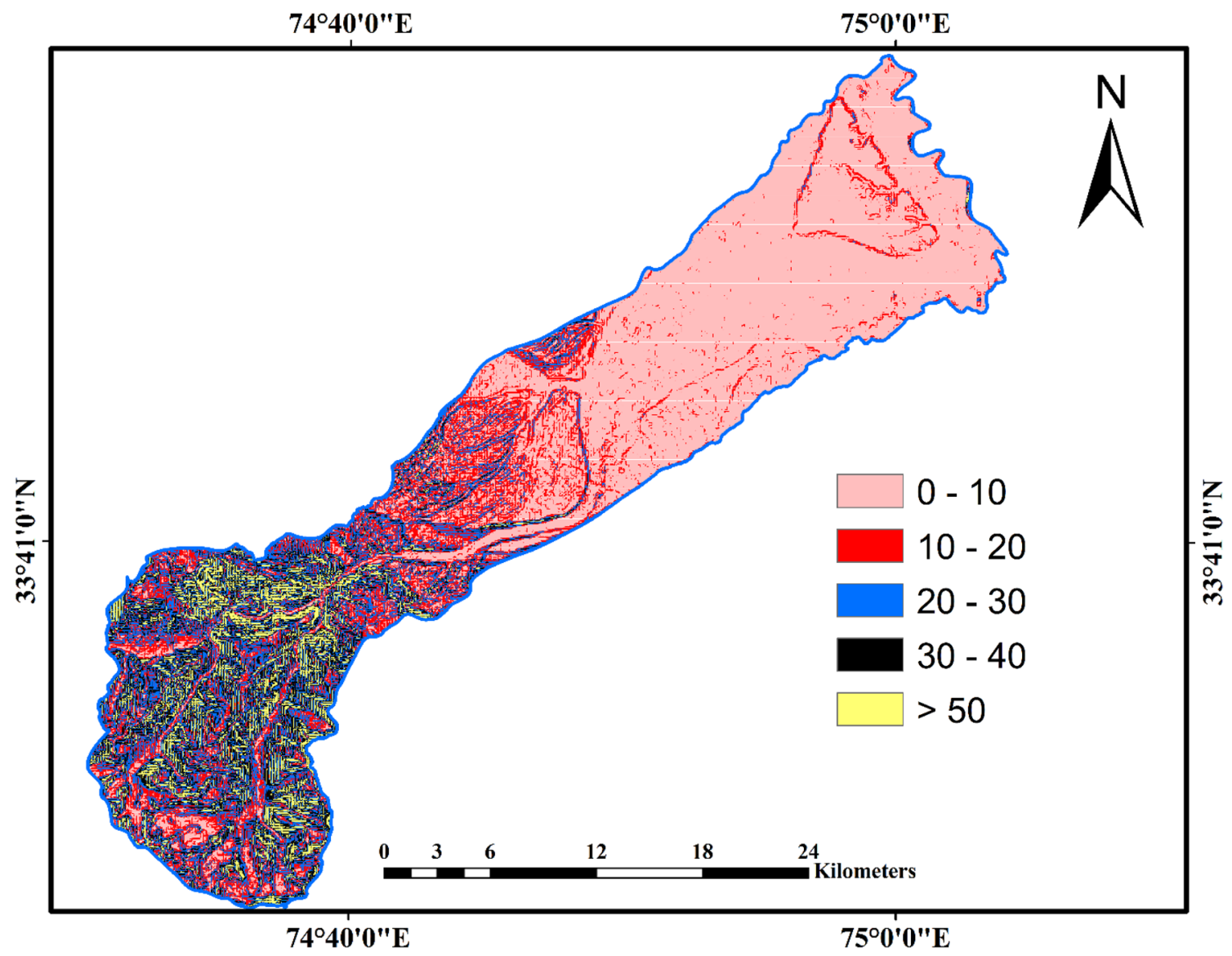

Fig. 8 Slope aspect map of the study area

\section{Conclusion}

Based on remote sensing and GIS techniques, a comprehensive map of unprecedented detail of groundwater potential in Rambiara river basin was prepared. The results obtained demonstrate that the most effective groundwater recharge potential zones are located downstream of the Rambiara river basin. In these zones, the presence of the alluvial plains, gentle slopes and cultivated land and forests supports high infiltration ability. Additionally, the concentration of drainage also indicates the ability of stream flow to recharge the groundwater system. The upstream region is least effective for groundwater recharge, mainly due to its igneous and metamorphic rock and steep slope dominance. This study has recognized the interrelationships between the groundwater recharge potential factors and the groundwater recharge potential scores from the general hydrology characteristics of Rambiara river basin. The results of the present study can assist as guidelines for planning future artificial recharge 


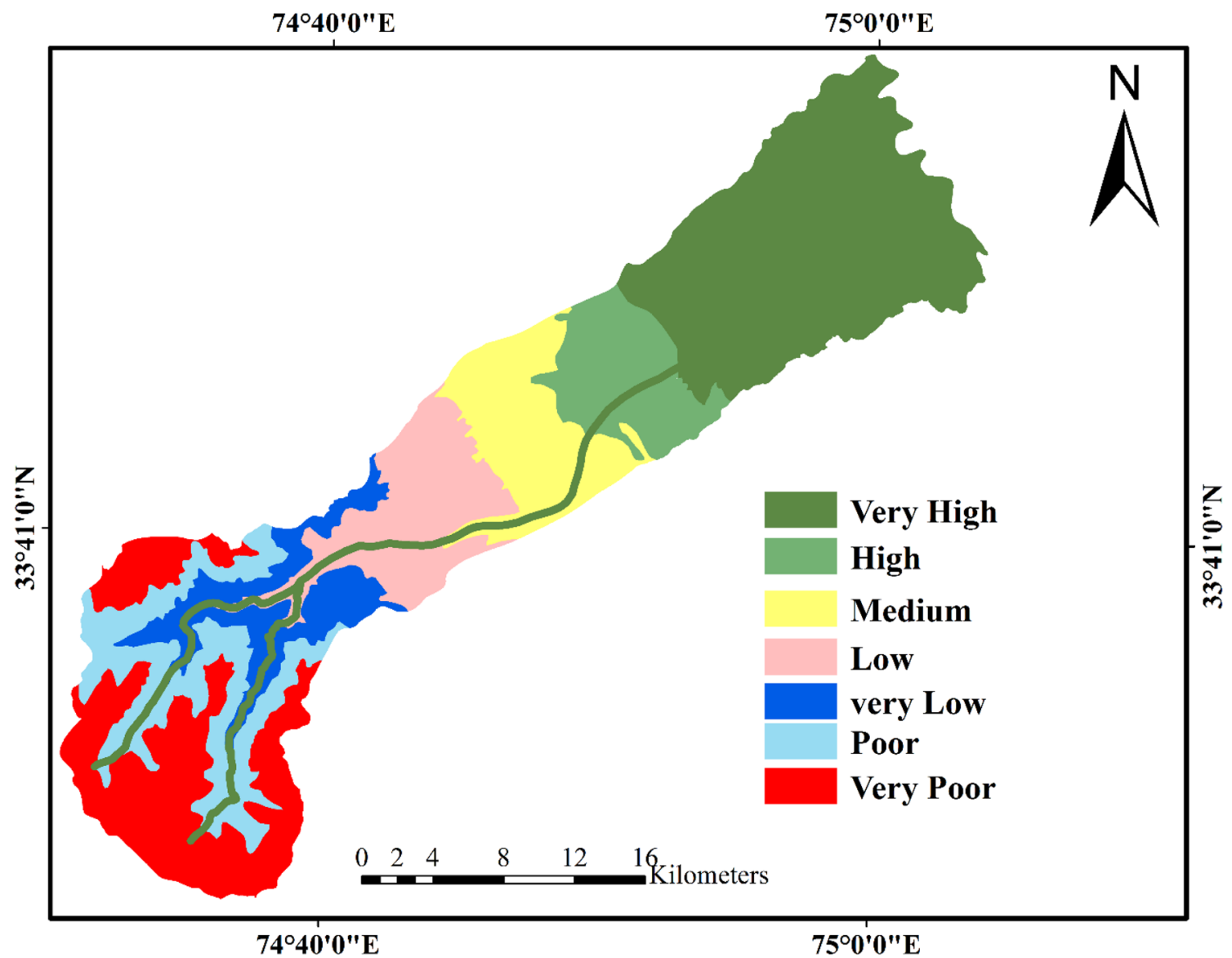

Fig. 9 Groundwater potential map of the Rambiara river basin

projects in the study area in order to ensure sustainable groundwater utilization and management.

Acknowledgements The authors thank the anonymous reviewers for their constructive comments that helped in better presentation of the data and the manuscript.

Open Access This article is distributed under the terms of the Creative Commons Attribution 4.0 International License (http://creativeco mmons.org/licenses/by/4.0/), which permits unrestricted use, distribution, and reproduction in any medium, provided you give appropriate credit to the original author(s) and the source, provide a link to the Creative Commons license, and indicate if changes were made.

\section{References}

Agarwal KK, Shah RA, Achyuthan H, Singh DS, Srivastava S, Khan I (2018) Neotectonic activity from Karewa sediments, Kashmir Himalaya, India. Geotecton 52:88-99. https://doi.org/10.1134/ S0016852118010028

Al-Abadi A, Al-Shamma'a A (2014) Groundwater potential mapping of the major aquifer in Northeastern Missan Governorate, South of Iraq by using analytical hierarchy process and GIS. J Environ Earth Sci 10:125-149

Ayele AF, Addis K, Tesfamichael G, Gebrerufael HA (2014) Spatial analysis of groundwater potential using remote sensing and GIS based multi-criteria evaluation in Raya valley, Northern Ethiopia. Hydrogeol J 23:195-206

Bhuvaneswaran C, Ganesh A, Nevedita S (2015) Spatial analysis of groundwater potential zones using remote sensing, GIS and MIF techniques in upparOdai sub-watershed, Nandiyar, Cauvery basin, Tamil Nadu. Int J Curr Res 7(09):20765-20774

Bobba AG, Bukata RP, Jerome JH (1992) Digitally processed satellite data as a tool in detecting potential groundwater flow systems. J Hydrol 131(1-4):25-62. https://doi.org/10.1016/00221694(92)90212-E

Fashae OA, Tijani MN, Talabi AO, Adedeji OI (2014) Delineation of groundwater potential zones in the crystalline basement terrain of SW-Nigeria: an integrated GIS and remote sensing approach. Appl Water Sci 4(1):19-38

Foster S (1998) Groundwater assessing vulnerability and promoting protection of a threatened resource. In: Proceedings of the 8th Stockholm water symposium, Sweden, pp 79-90

Gogu RC, Carabin G, Hallet V, Peters V, Dassargues A (2001) GIS based hydrogeological databases and groundwater modeling. Hydrogeol J 9:555-569. https://doi.org/10.1007/s1004 0-001-0167-3

Gossel W, Ebraheem AM, Wycisk P (2004) A very large scale GIS based groundwater flow model for the Nubian sandstone aquifer 
in Eastern Sahara (Egypt, northern Sudan and eastern Libya). Hydrogeol J 12(6):698-713. https://doi.org/10.1007/s 1004 0-004-0379-4

Greenbaum D (1985) Review of remote sensing application to groundwater exploration in basement and regolith. British Geological Survey, Nottingham, UK

Hussein AA, Govindu V, Nigusse AGM (2016) Evaluation of ground water potential using geospatial techniques. Appl Water Sci 7(5):2447-2461

Jasmin I, Mallikarjuna P (2015) Delineation of groundwater potential zones in Araniar River basin, Tamil Nadu, India: an integrated remote sensing and geographical information system approach. Environ Earth Sci 73(7):3833-3847. https://doi.org/10.1007/ s12665-014-3666-y

Lone SA, Lone AA, Jeelani G (2016) Characterization of groundwater potential of Sindh Watershed Western Himalayas. J Res Dev 16:29-41

Lone SA, Jeelani G, Deshpande RD, Shah RA (2017) Evaluating the sensitivity of glacier to climate by using stable water isotopes and remote sensing. Environ Earth Sci 76:598. https://doi. org/10.1007/s12665-017-6937-6

Magesh NS, Chandrasekar N, Soundranayagam JP (2011) Morphometric evaluation of Papanasam and Manimuthar watersheds, parts of Western Ghats, Tirunelveli district, Tamil Nadu India: a GIS approach. Environ Earth Sci 64:373. https://doi.org/10.1007/ s12665-010-0860-4

Mallick J, Singh CK, Al-Wadi H, Ahmed M, Rahman A, Shashtri S, Mukherjee S (2015) Geospatial and geostatistical approach for groundwater potential zone delineation. Hydrol Process 29(3):395-418. https://doi.org/10.1002/hyp.10153

Meijerink AMJ, Schultz GA, Engman ET (2000) Remote sensing in hydrology and water management. Springer, Berlin, pp 305-325

Nag SK, Ghosh P (2013) Delineation of groundwater potential zone in Chhatna Block, Bankura District, West Bengal, India using remote sensing and GIS techniques. Environ Earth Sci 70(5):2115-2127. https://doi.org/10.1007/s12665-012-1713-0

Pinto D, Shrestha S, Babel MS, Ninsawat S (2017) Delineation of groundwater potential zones in the Comoro watershed, Timor Leste using GIS, remote sensing and analytic hierarchy process
(AHP) technique. Appl Water Sci 7(1):503-519. https://doi. org/10.1007/s13201-015-0270-6

Sisay B (2010) Application of remote sensing and GIS for groundwater zone mapping: groundwater potential modeling of Northern Ada' a Plain (Modjo Catchment) using remote sensing and GIS. Saarbrücken, Germany

Soumen D (2014) Delineation of ground water prospect zones using remote sensing, GIS techniques - a case study of Baghmundi development block of Puruliya district, West Bengal. Int J Geol Earth Environ Sci 4(2):62-72

Terzer S, Wassenaar LI, Araguás-Araguás LJ, Aggarwal PK (2013) Global isoscapes for $\delta^{18} \mathrm{O}$ and $\delta^{2} \mathrm{H}$ in precipitation: improved prediction using regionalized climatic regression models. Hydrol Earth Syst Sci 17(11):4713-4728

Thakur VC, Rawat BS (1992) Geological map of the Western Himalaya 1:1,200,000, Pergamon, 1992

Todd DK, Mays LW (2005) Groundwater hydrology, 3rd edn. Wiley, New York, p 636

Tsakiris G (2004) Water resources management trends, prospects and limitations. In: Proceedings of the EWRA symposium on water resources management: risks and challenges for the 21 st century, 2-4 September 2004, Izmir, pp 1-6

Waikar ML, Nilawar AP (2014) Identification of groundwater potential zone using remote sensing and GIS technique. Int J Innov Res Sci Eng Technol 3:12163-12174

Watkins B, Lu YC, Hart G, Daughtry C (1997) The current state of precision farming. Food Rev Int 13(2):141-162

Yeh HF, Chang PH, Hsu KC, Lee CH (2007) Assessment of groundwater recharge in Chih-Pen and Jin-Lin Creek basins. In: Proceedings of 3rd conference on resources engineering in Taiwan, pp 1-15

Yeh HF, Lee CH, Hsu KC, Chang PH (2008) GIS for the assessment of the groundwater recharge potential zone. Environ Geol 58(1):185195. https://doi.org/10.1007/s00254-008-1504-9

Publisher's Note Springer Nature remains neutral with regard to jurisdictional claims in published maps and institutional affiliations. 